\title{
Expression of genes related to energy metabolism and the unfolded protein response in dairy cow mammary cells is affected differently during dietary supplementation with energy from protein and fat
}

\author{
K. Nichols, ${ }^{1,2 *}$ J. Dijkstra, ${ }^{1}$ H. van Laar, ${ }^{3}$ J. J. M. Kim, ${ }^{4}$ J. P. Cant, ${ }^{4}$ and A. Bannink ${ }^{2}$ \\ ${ }_{1}^{1}$ Animal Nutrition Group, Wageningen University and Research, PO Box 338, 6700 AH Wageningen, the Netherlands \\ ${ }^{2}$ Wageningen Livestock Research, Wageningen University and Research, PO Box 338, 6700 AH Wageningen, the Netherlands \\ ${ }^{3}$ Trouw Nutrition R\&D, PO Box 220, 5830 AE Boxmeer, the Netherlands \\ ${ }^{4}$ Department of Animal Biosciences, University of Guelph, Ontario N1G 2W1, Canada
}

\section{ABSTRACT}

Secretory capacity of bovine mammary glands is enabled by a high number of secretory cells and their ability to use a range of metabolites to produce milk components. We isolated RNA from milk fat to measure expression of genes involved in energy-yielding pathways and the unfolded protein response in mammary glands of lactating cows given supplemental energy from protein $(\mathrm{PT})$ and fat $(\mathrm{FT})$ tested in a $2 \times 2$ factorial arrangement. We hypothesized that PT and FT would affect expression of genes in the branched-chain AA catabolic pathway and tricarboxylic acid (TCA) cycle based on the different energy types (aminogenic versus lipogenic) used to synthesize milk components. We also hypothesized that the response of genes related to endoplasmic reticulum (ER) homeostasis via the unfolded protein response would reflect the increase in milk production stimulated by PT and FT. Fifty-six multiparous Holstein-Friesian dairy cows were fed a basal total mixed ration (34\% grass silage, $33 \%$ corn silage, $5 \%$ grass hay, and $28 \%$ concentrate on a dry matter basis) for a 28-d control period. Experimental rations were then fed for $28 \mathrm{~d}$, consisting of (1) low protein, low fat (LP/LF); (2) high protein, low fat (HP/LF); (3) low protein, high fat (LP/HF); or (4) high protein and high fat $(\mathrm{HP} / \mathrm{HF})$. To obtain the high-protein (HP) and high-fat (HF) diets, intake of the basal ration was restricted and supplemented isoenergetically (net energy basis) with $2.0 \mathrm{~kg} / \mathrm{d}$ rumen-protected protein (soybean + rapeseed, 50:50 mixture on dry matter basis) and $0.68 \mathrm{~kg} / \mathrm{d}$ hydrogenated palm fatty acids on a dry matter basis. RNA from milk fat samples collected on d 27 of each period underwent real-time quantitative PCR. Energy from protein increased expression of $B C A T 1$

Received October 18, 2018.

Accepted March 27, 2019.

*Corresponding author: kelly.nichols@wur.nl (branched-chain amino acid transferase 1) mRNA, but only at the LF level, and tended to decrease expression of mRNA encoding the main subunit of the branchedchain keto-acid dehydrogenase complex. mRNA expression of malic enzyme, a proposed channeling route for AA though the TCA cycle, was decreased by PT, but only at the LF level. Expression of genes associated with de novo fatty acid synthesis was not affected by PT or FT. Energy from fat had no independent effect on genes related to ER homeostasis. At the LF level, PT activated XBP1 (X-box binding protein 1) mRNA. At the HF level, PT increased mRNA expression of the gene encoding GADD34 (growth arrest and DNA damage-inducible 34 ). These findings support our hypothesis that mammary cells use aminogenic and lipogenic precursors differently for milk component production when dietary intervention alters AA and fatty acid supply. They also suggest that mammary cells respond to increased AA supply through mechanisms of ER homeostasis, dependent on the presence of FT.

Key words: mammary cell, unfolded protein response, tricarboxylic acid cycle, rumen-protected protein, hydrogenated palm fatty acid

\section{INTRODUCTION}

Milk synthesis exemplifies the intersection between whole-body and mammary metabolism involving glycolysis, hexoneogenesis, lipogenesis, and AA synthesis. The mammary gland of ruminants differs from that of nonruminant animals in that it is effectively unable to use glucose to synthesize fatty acids (FA); it relies on acetate as the primary substrate instead (Bauman et al., 1970). Further, the virtual absence of glucose6-phosphatase in lactating bovine mammary tissue is consistent with its inability to convert gluconeogenic substrates (including lactate, pyruvate, glycerol, and glutamate) to glucose (Scott et al., 1976). While the glucose moiety of lactose appears to primarily arise from free glucose, the galactose moiety of lactose may 
originate partly from hexose phosphate intermediates (Wood et al., 1958, 1965). Enzymes regulating intermediate flux through the tricarboxylic acid (TCA) cycle and expression of their genes respond to available substrate (Owen et al., 2002), but they have gone largely unexplored in bovine mammary secretory cells, particularly in response to changing dietary supply of aminogenic and lipogenic substrates.

Bovine mammary glands have a massive secretory capacity made possible by a high number of secretory cells, but the intracellular mechanisms by which metabolites and hormones stimulate milk component synthesis are incompletely understood. The mammalian target of rapamycin complex 1 (mTORC1) and integrated stress response (ISR) network have been implicated in acute regulation of protein synthesis in mammary epithelial cells in vitro (Burgos et al., 2010, 2013; Appuhamy et al., 2011) and during nutrient infusions lasting up to $36 \mathrm{~h}$ in vivo (Rius et al., 2010; Toerien et al., 2010); however, activation of mTORC1 and ISR signaling networks in mammary tissue does not explain the milk protein yield response to chronic nutritional intervention persisting over several days (Curtis et al., 2014; Doelman et al., 2015). Instead, endoplasmic reticulum (ER) biogenesis and secretory cell differentiation may be activated in response to longterm nutritional intervention (Nichols et al., 2017; Cant et al., 2018). Expression of mRNA coding for constituent proteins of the unfolded protein response (UPR) suggested that 5-d abomasal EAA infusions initiated a non-stress-related cellular adaptation to support milk protein secretion from mammary cells (Nichols et al., 2017).

Mammary biopsy is a common technique to obtain tissue for in vivo cell signaling analysis (Curtis et al., 2014; Doelman et al., 2015; Nichols et al., 2017). Disadvantages to mammary biopsy include the level of invasiveness and the postoperative recovery and care required, which pose limits on the frequency of sampling, the physiological state of the animal at the time of the procedure, and the number of animals that can be studied. An alternative source of mRNA is secretory cell cytoplasm trapped within milk fat globules during their secretion from mammary epithelial cells (Huston and Patton, 1990; Heid and Keenan, 2005). Cytoplasmic material is a small fraction of the bovine milk fat globule (Huston and Patton, 1990), but the high fat content of ruminant milk allows sufficient RNA to be obtained for gene expression analysis (Brenaut et al., 2012; Abdelatty et al., 2017). Compared with mammary biopsy, milk fat RNA collection is noninvasive and permits a large sample size, thereby allowing further characterization of mammary function to link genomic and phenotypic data across a variety of experiments.
We recently reported results on milk production, milk composition, and mammary gland metabolite utilization from an experiment comparing the addition of 17 $\mathrm{MJ} / \mathrm{d} \mathrm{NE}_{\mathrm{L}}$ from protein (energy from protein, $\mathbf{P T}$ ) or fat (energy from fat, FT) to a base diet (Nichols et al., 2018, 2019). Milk protein yield and mammary gland uptake of Arg, Ile, Leu, and Val increased in response to PT independent of FT level, and net intramammary catabolism of Ile, Leu, and Val increased, as indicated by the difference between their uptake and output in milk. Supplementation with PT also increased milk output of intramammary-synthesized de novo FA. In contrast, FT tended to increase milk protein yield, did not affect mammary net uptake or mammary uptake to milk output ratios of EAA, and had no effect on milk output of de novo FA; however, it increased output of preformed FA in milk. Considering these responses in milk production and mammary gland AA utilization, we hypothesized that expression of genes in the branched-chain AA (BCAA) catabolic pathway and TCA cycle would be affected differently by PT and FT based on the energy type (aminogenic versus lipogenic) available to the mammary gland. Furthermore, we hypothesized that genes related to the maintenance of ER homeostasis via the UPR would respond to nutritional intervention and reflect the increase in milk production achieved by supplementation with PT and FT. Therefore, using RNA isolated from milk fat, we investigated mammary gland expression of genes related to catabolism of AA (particularly BCAA), lipogenesis, and ER homeostasis in lactating dairy cows after $27 \mathrm{~d}$ of energy supplementation from protein or fat.

\section{MATERIALS AND METHODS}

\section{Experimental Design}

Experimental procedures were approved by the Animal Care and Use Committee for Nutreco Nederland B.V. (Amersfoort, the Netherlands) and conducted under the Dutch Law on Animal Experiments. The experimental design and treatment diets have been thoroughly described by Nichols et al. (2018). Briefly, 56 Holstein-Friesian cows (20 primiparous, $138 \pm 64$ DIM; 36 multiparous, $3.7 \pm 1.8$ lactations, $181 \pm 93$ DIM) were used in a randomized complete block design in which supplemental PT or FT was tested in a factorial arrangement over 2 successive periods (control and experimental), each consisting of $21 \mathrm{~d}$ of diet adaptation and $7 \mathrm{~d}$ of data collection. A basal diet $(34 \%$ grass silage, $33 \%$ corn silage, $5 \%$ grass hay, and $28 \%$ concentrate on a DM basis) designed to meet $\mathrm{NE}_{\mathrm{L}}$ and MP requirements was fed as a TMR during the control period. Cows were blocked by parity, DIM, and 
DMI in the final $7 \mathrm{~d}$ of the control period, and then randomly assigned within blocks to 1 of 4 diets for the experimental period: (1) low protein, low fat $(\mathbf{L P} / \mathbf{L F}$; 95\% MP, 95\% $\left.\mathrm{NE}_{\mathrm{L}}\right)$, (2) high protein, low fat $(\mathbf{H P} /$ LF; $131 \%$ MP, $107 \% \mathrm{NE}_{\mathrm{L}}$ ), (3) low protein, high fat (LP/HF; $95 \%$ MP, $107 \% \mathrm{NE}_{\mathrm{L}}$ ), or (4) high protein and high fat ( $\left.\mathbf{H P} / \mathbf{H F} ; 131 \% \mathrm{MP}, 119 \% \mathrm{NE}_{\mathrm{L}}\right)$, where $\mathrm{MP}$ and $\mathrm{NE}_{\mathrm{L}}$ are expressed relative to animal requirements in the control period. For all treatments, basal diet intake for individual cows was restricted to $95 \%$ of their ad libitum intake recorded during the control period. To obtain the HP and HF diets, $2.0 \mathrm{~kg}$ of 50:50 mixture (DM basis) of a rumen-protected soybean meal and rapeseed meal (SoyPass + RaPass; both rumenprotected by xylose treatment; Borregaard LignoTech, Sarpsborg, Norway) and $0.68 \mathrm{~kg}$ of rumen-inert hydrogenated long-chain FA (Hidropalm; Norel, Madrid, Spain) on a DM basis were added to the concentrate portion of each basal TMR such that they provided the additional daily intake of $\mathrm{MP}$ and $\mathrm{NE}_{\mathrm{L}}$ (Nichols et al., 2018). The TMR were mixed and distributed once daily at $1000 \mathrm{~h}$ via electronic intake boxes (Insentec, Marknesse, the Netherlands) that recorded feed intake of individual animals. Cows were housed in a freestall barn and had ad libitum access to drinking water throughout the entire experiment. Cows were milked twice daily at 0530 and $1630 \mathrm{~h}$ and milk production was recorded electronically. Details of milk sampling and the analysis of lactose, protein, and fat composition have been described by Nichols et al. (2018).

\section{Milk Fat Collection, RNA Extraction, and Real-Time Quantitative PCR}

During morning milking on d 27 of each period, 10 $\mathrm{mL}$ of milk was collected from individual cows by hand into sterile centrifuge tubes directly after the milking machine was removed. This approach was taken to reduce the impact of inherent RNase activity in milk on RNA quality by minimizing the amount of time between alveolar ejection of fresh milk and placing the collected milk fat into RNase inhibitor. Samples were immediately stored at $4^{\circ} \mathrm{C}$. Within $1 \mathrm{~h}$ of collection, milk samples were centrifuged at 2,000 $\times g$ for $10 \mathrm{~min}$ at $4^{\circ} \mathrm{C}$ to facilitate separation of the fat fraction. Approximately $1 \mathrm{~g}$ of the supernatant cream layer was transferred into $6 \mathrm{~mL}$ of TRI Reagent (Sigma Aldrich, St. Louis, MO), mixed vigorously, snap frozen in liquid $\mathrm{N}_{2}$, and stored at $-80^{\circ} \mathrm{C}$ until RNA extraction. Total RNA was isolated from milk fat according to TRI Reagent manufacturer's instructions for handling samples with a high fat content. Total RNA concentrations and purity were determined by optical density measurement using a Nano-Drop ND-1000 (ThermoFisher Scientific,
Waltham, MA). The average $260 / 280$ absorbance ratio of total RNA samples was $1.57 \pm 0.17$ (mean $\pm \mathrm{SD}$ ). All samples showed an RNA integrity number greater than 6.0, which was determined using an Agilent 2100 Bioanalyzer (Agilent Technologies, Santa Clara, CA). An aliquot of $100 \mathrm{ng}$ of total RNA was reverse transcribed with Superscript III (ThermoFisher Scientific) in the presence of random hexamers $(250 \mathrm{ng} / \mu \mathrm{L}$; Roche, Almere, the Netherlands) and dNTPs (10 $\mathrm{m} M$; Roche) at $25^{\circ} \mathrm{C}$ for $5 \mathrm{~min}, 50^{\circ} \mathrm{C}$ for $1 \mathrm{~h}$, and $70^{\circ} \mathrm{C}$ for $15 \mathrm{~min}$, and cDNA was stored at $-80^{\circ} \mathrm{C}$ until further analysis.

Primers (Integrated DNA Technologies, Coralville, IA) were designed to yield PCR amplification products of 100 to $200 \mathrm{bp}$ (Table 1) with efficiencies between 90 and $100 \%$. Real-time quantitative PCR was carried out with an Applied Biosystems 7300 Real Time PCR instrument, using $5 \mu \mathrm{L}$ of diluted cDNA combined with a $15-\mu \mathrm{L}$ mixture composed of $10 \mu \mathrm{L}$ of PerfeCTa SYBR Green FastMix (Quanta BioSciences, Gaithersburg, MD), $0.4 \mu M$ forward and reverse primers, and DNase/ RNase-free water. Housekeeping genes glyceraldehyde 3-phosphate dehydrogenase (GAPDH), H3 histone class 3 (H3F3A), and ribosomal protein S9 (RPS9) served as internal standards in gene expression analysis, and NormFinder (Andersen et al., 2004) identified H3F3A as the most stable across block and treatment. Fold changes in gene expression relative to the mean of each treatment in the control period were calculated by the $2^{-\Delta \Delta \mathrm{Ct}}$ method (Livak and Schmittgen, 2001), with H3F3A used as the reference gene.

\section{Statistical Analysis}

Variances in gene expression were analyzed using the MIXED procedure of SAS (SAS Institute Inc., Cary, NC) with level of protein and fat and their interaction included as fixed effects and block included as a random factor. Milk and component production was analyzed using the same model, but data from the final week of the control period were used as covariates (described in detail by Nichols et al., 2018). Differences were considered significant at $P \leq 0.05$ and tendencies at $0.05<P \leq 0.10$. Multiple comparisons between treatment means were made using the Tukey-Kramer method when a PT $\times$ FT interaction was detected at $P \leq 0.10$.

\section{RESULTS}

\section{Milk Production}

Neither production of total milk nor production of milk components was affected by a PT $\times$ FT interaction (Table 2). Milk yield increased $1.9 \mathrm{~kg} / \mathrm{d}$ in response 


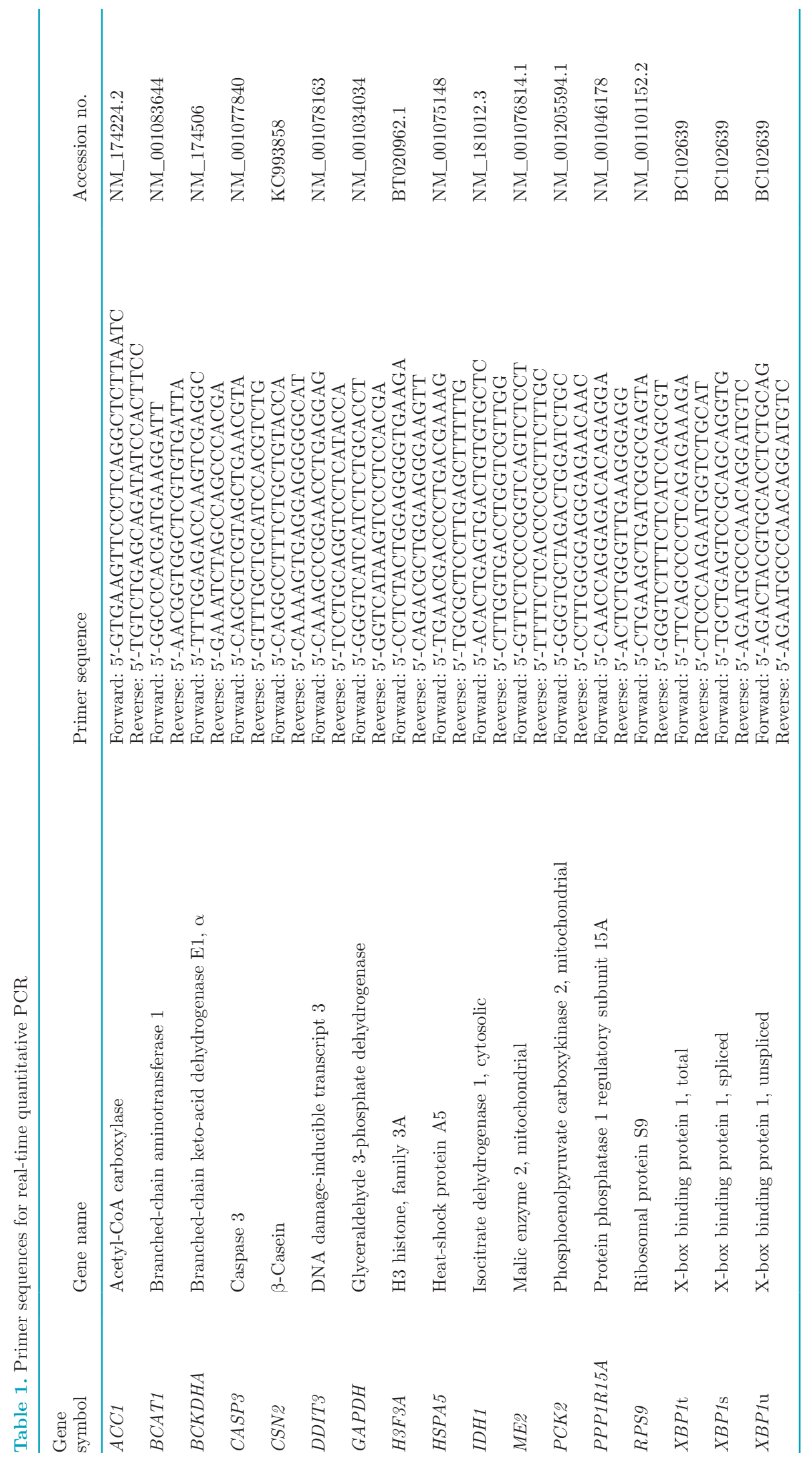


Table 2. Milk and component yield (kg/d) from lactating dairy cows fed the basal diet (LP/LF) or diets supplemented with energy from protein $(\mathrm{HP} / \mathrm{LF})$, fat $(\mathrm{LP} / \mathrm{HF})$, or from protein and fat $(\mathrm{HP} / \mathrm{HF})^{1}$

\begin{tabular}{|c|c|c|c|c|c|c|c|c|}
\hline \multirow[b]{2}{*}{ Item } & \multicolumn{4}{|c|}{ Treatment $^{2}$} & \multirow[b]{2}{*}{ SEM } & \multicolumn{3}{|c|}{$P$-value ${ }^{3}$} \\
\hline & $\mathrm{LP} / \mathrm{LF}$ & $\mathrm{HP} / \mathrm{LF}$ & $\mathrm{LP} / \mathrm{HF}$ & $\mathrm{HP} / \mathrm{HF}$ & & $\mathrm{PT}$ & FT & $\mathrm{PT} \times \mathrm{FT}$ \\
\hline Lactose & 1.21 & 1.31 & 1.30 & 1.38 & 0.031 & $<0.01$ & 0.01 & 0.66 \\
\hline Protein & 0.92 & 1.01 & 0.97 & 1.04 & 0.024 & $<0.01$ & 0.05 & 0.50 \\
\hline Fat & 1.20 & 1.25 & 1.33 & 1.38 & 0.033 & 0.10 & $<0.01$ & 0.93 \\
\hline
\end{tabular}

${ }^{1}$ Data are least squares means from the final week of the experimental period using data from the final week of the control period as covariates for each parameter (see Nichols et al., 2018, for further details).

${ }^{2} \mathrm{LP} / \mathrm{LF}=$ basal TMR with no protein or fat supplement fed at $95 \%$ of ad libitum intake of control period; HP $/ \mathrm{LF}=\mathrm{TMR}$ fed at $95 \%$ of ad libitum intake of control period supplemented daily with $2.0 \mathrm{~kg}$ of SoyPass (Borregaard LignoTech, Sarpsborg, Norway) + RaPass (Borregaard LignoTech) on a DM basis; $\mathrm{LP} / \mathrm{HF}=\mathrm{TMR}$ fed at $95 \%$ of ad libitum intake of control period supplemented daily with $0.68 \mathrm{~kg}$ of Hidropalm (Norel, Madrid, Spain) on a DM basis; HP/HF = TMR fed at $95 \%$ of ad libitum intake of control period supplemented daily with $2.0 \mathrm{~kg}$ of SoyPass + RaPass and $0.68 \mathrm{~kg}$ of Hidropalm on a DM basis. For all treatments $\mathrm{n}=14$.

${ }^{3} \mathrm{PT}=$ effect of energy from protein; $\mathrm{FT}=$ effect of energy from fat.

to $\mathrm{PT}(P=0.01)$ and $1.6 \mathrm{~kg} / \mathrm{d}$ in response to $\mathrm{FT}(P$ $=0.03)$. Lactose yield increased 7 and $6 \%$ in response to $\mathrm{PT}$ and $\mathrm{FT}$, respectively $(P \leq 0.01)$. Milk protein yield increased $8 \%$ in response to $\mathrm{PT}(P<0.01)$ and increased $4 \%$ in response to FT $(P=0.05)$. Milk fat yield tended to increase in response to PT $(P=0.10)$ and increased $11 \%$ in response to FT $(P<0.01)$.

\section{mRNA Expression}

Expression of genes related to AA catabolism and energy metabolism is presented in Table 3. Expression of $B C A T 1$ mRNA increased in response to PT, but only at the LF level $(\mathrm{PT} \times \mathrm{FT}$ interaction; $P=0.02)$. Expression of $B C K D H A$ tended to decrease in response to PT $(P=0.08)$. Expression of $M E 2$ was affected by a PT $\times$ FT interaction $(P=0.05$; Table 3$)$, where PT decreased ME2 expression, but only on the LF diet. Expression of ACC1, CSN2, IDH1, and PCK2 was not affected by PT or FT $(P \geq 0.13)$.

Expression of genes related to the control of ER homeostasis and secretory cell differentiation are presented in Table 4. Expression of PPP1R15A increased in response to $\mathrm{PT}$ on the $\mathrm{HF}$ diet but not on the $\mathrm{LF}$ diet (tendency for $\mathrm{PT} \times \mathrm{FT}$ interaction; $P=0.06$ ). Expression of CASP3, DDIT3, and HSPA5 was not affected by PT or FT $(P \geq 0.18)$. The expression of total $(\mathbf{t})$, spliced (s), and unspliced $(\mathbf{u}) X B P 1$ was not affected by PT or FT. The proportion of $X B P 1 \mathrm{~s}$ to $X B P 1 \mathrm{u}$ increased in response to $\mathrm{PT}(P<0.01)$, but a tendency for a PT $\times$ FT interaction $(P=0.06)$ indicates a response to $\mathrm{PT}$ on $\mathrm{LF}$ diets only. In response to FT, the proportion of $X B P 1$ s to $X B P 1 \mathrm{u}$ tended to increase $(P=0.10)$, but only at the HP level $(\mathrm{PT} \times$

Table 3. Mammary gland expression (arbitrary units) of genes for milk protein, AA catabolism, and energy-yielding pathways in lactating dairy cows fed the basal diet $(\mathrm{LP} / \mathrm{LF})$ or diets supplemented with energy from protein $(\mathrm{HP} / \mathrm{LF})$, fat $(\mathrm{LP} / \mathrm{HF})$, or from protein and fat $(\mathrm{HP} / \mathrm{HF})^{1}$

\begin{tabular}{|c|c|c|c|c|c|c|c|c|}
\hline Gene & \multicolumn{4}{|c|}{ Treatment $^{2}$} & SEM & \multicolumn{3}{|c|}{$P$-value ${ }^{3}$} \\
\hline$A C C 1$ & 3.96 & 3.62 & 5.31 & 4.18 & 1.120 & 0.49 & 0.37 & 0.72 \\
\hline ВCKDHA & 0.85 & 0.72 & 1.36 & 0.47 & 0.341 & 0.08 & 0.65 & 0.20 \\
\hline CSN2 & 2.24 & 1.38 & 3.46 & 1.53 & 0.861 & 0.13 & 0.45 & 0.55 \\
\hline IDH1 & 2.66 & 2.61 & 2.81 & 2.12 & 0.700 & 0.49 & 0.74 & 0.54 \\
\hline
\end{tabular}

${ }^{\mathrm{a}, \mathrm{b}}$ Means within a row with no common superscripts differ $(P \leq 0.05)$.

${ }^{1}$ Values are least squares means of fold changes in gene expression from RNA captured in milk fat globules relative to the mean of each treatment in the control period calculated by the $2^{-\Delta \Delta \mathrm{Ct}}$ method after normalizing to H3F3A.

${ }^{2} \mathrm{LP} / \mathrm{LF}=$ basal TMR with no protein or fat supplement fed at $95 \%$ of ad libitum intake of control period; HP $/ \mathrm{LF}=\mathrm{TMR}$ fed at $95 \%$ of ad libitum intake of control period supplemented daily with $2.0 \mathrm{~kg}$ of SoyPass (Borregaard LignoTech, Sarpsborg, Norway) + RaPass (Borregaard LignoTech) on a DM basis; LP/HF = TMR fed at $95 \%$ of ad libitum intake of control period supplemented daily with $0.68 \mathrm{~kg}$ of Hidropalm (Norel, Madrid, Spain) on a DM basis; HP/HF = TMR fed at $95 \%$ of ad libitum intake of control period supplemented daily with $2.0 \mathrm{~kg}$ of SoyPass + RaPass and $0.68 \mathrm{~kg}$ of Hidropalm on a DM basis. For all treatments $\mathrm{n}=14$.

${ }^{3} \mathrm{PT}=$ effect of energy from protein; $\mathrm{FT}=$ effect of energy from fat. 
Table 4. Mammary gland expression (arbitrary units) of genes for endoplasmic reticulum homeostasis and secretory cell differentiation in lactating dairy cows fed the basal diet (LP/LF) or diets supplemented with energy from protein (HP/LF), fat (LP/HF), or from protein and fat $(\mathrm{HP} / \mathrm{HF})^{1}$

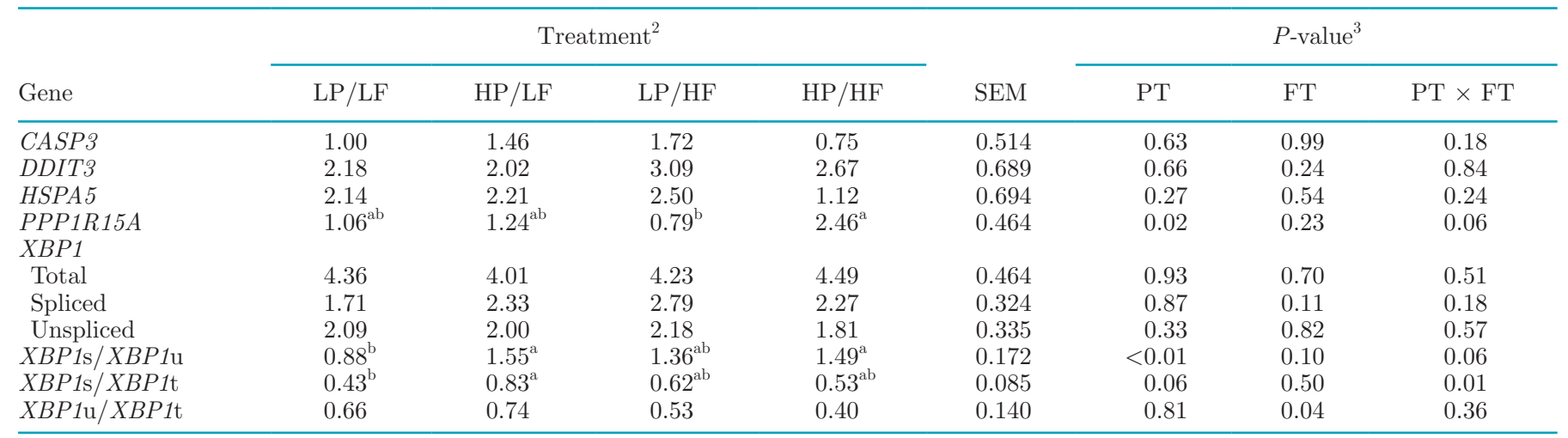

${ }^{\mathrm{a}, \mathrm{b}}$ Means within a row with no common superscripts differ $(P \leq 0.05)$.

${ }^{1}$ Values are least squares means of fold changes in gene expression from RNA captured in milk fat globules relative to the mean of each treatment in the control period calculated by the $2^{-\triangle \Delta \mathrm{Ct}}$ method after normalizing to H3F3A.

${ }^{2} \mathrm{LP} / \mathrm{LF}=$ basal TMR with no protein or fat supplement fed at $95 \%$ of ad libitum intake of control period; HP/LF $=\mathrm{TMR}$ fed at $95 \%$ of ad libitum intake of control period supplemented daily with $2.0 \mathrm{~kg}$ of SoyPass (Borregaard LignoTech, Sarpsborg, Norway) + RaPass (Borregaard LignoTech) on a DM basis; LP/HF = TMR fed at $95 \%$ of ad libitum intake of control period supplemented daily with $0.68 \mathrm{~kg}$ of Hidropalm (Norel, Madrid, Spain) on a DM basis; HP $/ \mathrm{HF}=$ TMR fed at $95 \%$ of ad libitum intake of control period supplemented daily with $2.0 \mathrm{~kg}$ of SoyPass + RaPass and $0.68 \mathrm{~kg}$ of Hidropalm on a DM basis. For all treatments $\mathrm{n}=14$.

${ }^{3} \mathrm{PT}=$ effect of energy from protein; $\mathrm{FT}=$ effect of energy from fat.

FT interaction; $P=0.06)$. The proportion of $X B P 1$ s to $X B P 1$ t tended to increase with PT $(P=0.06)$, but only at the $\mathrm{LF}$ level $(\mathrm{PT} \times \mathrm{FT}$ interaction; $P=0.01)$. The proportion of $X B P 1 \mathrm{u}$ to $X B P 1 \mathrm{t}$ decreased in response to FT $(P=0.04)$.

\section{DISCUSSION}

This study analyzed gene expression from RNA captured in milk fat globules. This technique has been demonstrated to yield RNA profiles and gene expression comparable to those obtained from mammary tissue in lactating primates (Maningat et al., 2007; Lemay et al., 2013), goats (Brenaut et al., 2012), and cows (Cánovas et al., 2014; Abdelatty et al., 2017). Using a collection technique similar to that described in the current study, Brenaut et al. (2012) showed that RNA obtained from caprine milk fat globules quantitatively represented the transcriptional information found in mammary epithelial cells. The quality of RNA obtained in the current study, measured by purity and RNA integrity, is comparable to previous studies that have reported mammary gene expression and transcriptome measurements from milk fat RNA (Brenaut et al., 2012; Cánovas et al., 2014; Abdelatty et al., 2017). Regarding the technique's suitability for investigating gene expression in response to nutritional intervention, Abdelatty et al. (2017) analyzed gene expression from milk fat RNA after $40 \%$ feed restriction in lactating dairy cows and detected changes in mRNA expression of several lipo- genic genes. In the current study, genes were selected to relate the observed effects of $\mathrm{PT}$ and FT on milk production to mammary cell AA and energy metabolism. Further, genes related to the UPR and ER homeostasis were selected based on their response to postruminal EAA infusions as identified by Nichols et al. (2017).

\section{Energy-Yielding Pathways}

Intermediates of BCAA catabolism contribute anaplerotically to the TCA cycle (Owen et al., 2002). The cytosolic form of BCAA aminotransferase (BCAT), encoded by BCAT1, catalyzes the first step of BCAA degradation through reversible transamination of Ile, Leu, and Val, yielding their respective branched-chain $\alpha$-keto acids (BCKA) and glutamate. Glutamate may be used for de novo synthesis of other NEAA, and BCKA are reaminated to BCAA and released into blood, or decarboxylated by branchedchain keto-acid dehydrogenase complex (BCKDH), of which the main E1 $\alpha$-subunit is encoded by $B C K$ $D H A$. Decarboxylation of BCKA is an irreversible and controlling step in BCAA catabolism and yields CoA derivatives that enter the TCA cycle for oxidation or further incorporation into NEAA or FA (Brosnan and Brosnan, 2006). The BCAA are taken up by bovine mammary glands in excess of their output in milk protein and are catabolized via BCAT and BCKDH (Davis and Mepham, 1976; Wohlt et al., 1977). Increasing MP supply causes faster intramammary 
BCAA catabolism (Bequette et al., 1996a,b; Raggio et al., 2006).

We hypothesized that BCAA catabolism would increase at the HP level, but to our knowledge, effects of diet (energy type and supply) on expression of genes for BCAA catabolism in bovine mammary glands have not been reported. Increased expression of BCAT1 mRNA in response to PT (at the LF level only), suggests upregulation of intramammary BCAA catabolism and their use for NEAA synthesis. This possibility agrees with our findings that mammary uptake of BCAA in excess of milk output increased in response to PT, and that the deficit between output and uptake of glutamate was larger at the HF level (Nichols et al., 2019). The tendency for decreased BCKDHA expression in response to PT agrees with findings by DeSantiago et al. (1998), who reported a high ratio of BCAT to BCKDH activity in rat mammary tissue, which suggests oxidation is not the fate of all BCKA after BCATmediated transamination. Indeed, upwards of $80 \%$ of BCAA incorporated into milk protein may be reversibly transaminated before incorporation (Roets et al., 1979, 1983). Infusing a complete mixture of AA into goats increased the rate of mammary Leu transamination without a concomitant increase in flux through BCKDH (Bequette et al., 2002). In other experiments, increasing AA supply resulted in faster rates of both transamination and oxidation of Leu in the mammary glands (Bequette et al., 1996a; Raggio et al., 2006). Inconsistencies in the response between $B C A T 1$ and $B C K D H A$ expression may be related to the suggestion of DeSantiago et al. (1998) that, based on differences between lactating and virgin rats, BCKA flux through mammary $\mathrm{BCKDH}$ is regulated primarily by its phosphorylation state and not mRNA or protein expression.

Addition of PT to the HF diet did not increase $B C A T 1$ expression as it did with the LF diet, suggesting that FT inhibited upregulation of BCAT1 expression. However, excess BCAA uptake over milk output, representing net catabolism, was not affected by $\mathrm{FT}$ (Nichols et al., 2019). Changes in catabolic flux are due to a combination of effects on enzyme expression and substrate concentrations. Similar to the effect on $B C A T 1$ expression, $\mathrm{PT} \times \mathrm{FT}$ interactions were detected by Nichols et al. (2019) for arterial concentrations of the individual BCAA, acetate, BHB, and insulin, and a tendency for a PT $\times$ FT interaction on plasma flow to the gland, where PT effects were smaller or absent on HF versus LF diets. Regulation on the supply of major fuels for the TCA cycle, such as acetate and BHB, through physiological adaptations such as mammary blood flow, may influence catabolism of other substrates independent of enzyme expression. Energy from fat increased uptake of long-chain FA by the mammary gland (Nichols et al., 2019). Reduced requirements for TCA cycle intermediates to generate $\mathrm{NADPH}$ for de novo FA synthesis in response to FT may also figure into the lack of induction of $B C A T 1$ expression by PT on HF diets. The net result of higher AA and long-chain FA supply on $\mathrm{HP} / \mathrm{HF}$ was faster intramammary BCAA catabolism, but it had no effect on BCAT1 at the level of mRNA expression.

Interest in the mitochondrial isoforms of malic enzyme (ME), encoded by ME2, and phosphoenolpyruvate carboxykinase (PEPCK), encoded by PCK2, in mammary secretory cells arose because they allow channeling of TCA cycle intermediates derived from NEAA and group $2 \mathrm{AA}$, including Ile and Val, to pyruvate (Pongratz et al., 2007; Méndez-Lucas et al., 2014). The mitochondrial PEPCK isoform facilitates conversion of AA and other substrates entering at or beyond succinyl-CoA into $\mathrm{C}$ skeletons of NEAA and supports oxidation in the TCA cycle via pyruvate (Scott et al., 1976; Agca et al., 2002). As such, when intramammary BCAA are used for de novo NEAA synthesis in support of milk protein yield, this pathway may be upregulated. Mitochondrial ME converts C skeletons of AA (AAC) to pyruvate, independent of glycolytic flux, to increase oxidative flux through pyruvate dehydrogenase in response to increased AA concentrations (Mandella and Sauer, 1975; Pongratz et al., 2007). This pathway appears to be important when glucose is used for biosynthesis and is not the main fuel for the TCA cycle (Chang and Tong, 2003), such as in mammary secretory cells. Data on gene expression or protein activity of the mitochondrial isoforms of PEPCK and ME in response to energy or protein supply are scarce in lactating bovine mammary glands. Because intramammary BCAA catabolism increased with $\mathrm{PT}$, we hypothesized that PCK2 and ME2 expression would increase to support AA-C flux through the TCA cycle, allowing glucose to support the increase in lactose yield with PT. In response to $\mathrm{FT}$, we expected no effect due to the lower AA supply to mammary cells.

Energy from protein decreased ME2 expression, in contrast to our hypothesis, but only with the LF diet. On $\mathrm{HP} / \mathrm{LF}$, intramammary BCAA transamination increased, as indicated by the increase in BCAT1 expression, but oxidation of BCKA may have contributed relatively less to the AA-C pool, which is suggested by the tendency for decreased $B C K D H A$ expression in response to PT. Reduced ME2 expression could be expected if fewer CoA derivatives from AA-C skeletons require shuttling toward pyruvate via $\mathrm{ME}$. This pattern in mRNA expression of ME2, BCAT1, and BCKDHA may suggest a link between these enzymes in the contribution of AA catabolism to anaplerotic flux through the TCA cycle, while a potential role of mitochondrial 
PECPK remains undetermined in lactating bovine mammary glands.

Cytosolic NADP-linked isocitrate dehydrogenase (IDH) 1, encoded by IDH1, catalyzes the conversion of isocitrate to $\alpha$-ketoglutarate (Koh et al., 2004) and generates the primary source of NADPH for de novo FA synthesis (Bauman et al., 1970; Farrell et al., 1987). Incubation with palmitic acid decreased IDH1 expression in bovine mammary epithelial cells (Liu et al., 2006). Acetyl-CoA carboxylase (ACC) 1, encoded by $A C C 1$, catalyzes the first step in de novo FA synthesis. Some studies have shown that mammary $A C C 1$ expression decreases when milk fat-depressing diets are fed to dairy cows (Piperova et al., 2000; Ahnadi et al., 2002; Peterson et al., 2003), but other studies have not (Bernard et al., 2017). In contrast to studies in which diets are designed to induce milk fat depression and subsequent decreases in lipogenic gene expression are detected (Piperova et al., 2000; Baumgard et al., 2002; Peterson et al., 2003), supplementation with rumeninert, hydrogenated palm FA in the current experiment increased milk fat yield and we observed no change in IDH1 or ACC1 expression in response to PT or FT. Although de novo FA concentration in milk fat decreased with $\mathrm{FT}$, the increase in total fat yield resulted in no change in de novo FA yield (Nichols et al., 2018), in agreement with no effects on $I D H 1$ or $A C C 1$. In contrast, PT increased de novo FA concentration in milk but had no effect on total fat yield, resulting in greater de novo FA yield but no increase in $I D H 1$ or $A C C 1$ expression. The increase in de novo FA synthesis in response to PT may not have been extreme enough to affect IDH1 or $A C C 1$ at the mRNA expression level. Furthermore, Wright et al. (2006) concluded that ACC1 exerts strong control on flux but not rate-limiting control over FA synthesis, which could be more heavily influenced by the enzyme FA synthase.

\section{Mammary Cell UPR and ER Biogenesis}

Evidence suggests that energy source and supply do not directly affect expression of milk protein genes in dairy cattle and goats (Boutinaud et al., 2008; Ollier et al., 2009; Nichols et al., 2017). In agreement with these previous observations, we found that expression of CSN2, which encodes $\beta$-casein, was not affected by PT or FT, but milk protein yield was increased. Instead, rate of milk protein synthesis may be affected by nutritional intervention through mechanisms such as altered mRNA translation efficiency and number or synthetic capacity of milk secretory cells (Cant et al., 2018). Signaling cascades of the constituent UPR play a crucial role in defining the phenotype and maintaining the function of differentiated secretory cells, such as antibody-secreting plasma cells (Reimold et al., 2001), gastric zymogenic cells (Huh et al., 2010), pancreatic endocrine and exocrine cells (Harding et al., 2001), and mammary secretory cells (Davis et al., 2016; Tsuchiya et al., 2017). Initiation of the UPR during protein misfolding in mammalian cells occurs by dissociation of the ER chaperone binding immunoglobulin protein $(\mathrm{BiP} /$ GRP78), encoded by HSPA5 (Hetz et al., 2015), onto 3 ER transmembrane proteins initiating the 3 UPR arms, namely protein kinase R-like endoplasmic reticulum kinase (PERK), activating transcription factor 6 (ATF6), and inositol-requiring enzyme 1 (IRE1). In the first UPR arm, phosphorylation of PERK activates the ISR network (Proud, 2005) suppressing global protein synthesis, decreasing the load of new proteins on the ER, and stimulating translation of activating transcription factor 4 (ATF4) and its targets, the pro-apoptotic C/EBP homologous protein (CHOP), encoded by DDIT3, and growth arrest and DNA damage-inducible 34 (GADD34), encoded by PPP1R15A (Walter and Ron, 2011). GADD34 dephosphorylates ISR constituents, counteracting the effects of PERK, to resume protein synthesis once the ER has returned to homeostatic function (Ma and Hendershot, 2003). The second arm of the UPR, through ATF6, encourages ER biogenesis and activates transcription of XBP1 and HSPA5 (Hetz et al., 2015). The third UPR arm, mediated by phosphorylated IRE1 after BiP/GRP78 release, excises $X B P 1 \mathrm{mRNA}$ to generate the active spliced form $X B P 1 \mathrm{~s}$. The product of $X B P 1$ s translation is a transcription factor that stimulates expression of proteins involved in differentiation of the secretory phenotype, rough ER formation and expansion, and secretory vesicle maturation (Sriburi et al., 2004; Huh et al., 2010; Yonekura et al., 2018). If UPR signaling cascades fail to promote ER functionality, pro-apoptotic signals emerge through CHOP and effector caspases (Hetz et al., 2015).

We hypothesized that the UPR would be implicated in mammary cells to reflect the increase in milk component secretion observed in response to PT and FT. A lack of effect on expression of DDIT3, HSPA5, and $X B P 1 \mathrm{t}$ suggests that neither the second arm nor the pro-apoptotic element of the first arm of the UPR was affected by PT or FT. As part of the UPR, PPP1R15A and DDIT3 expression levels may change in parallel under the control of ATF4. Indeed, Nichols et al. (2017) found that expression of PPP1R15A and DDIT3 decreased after $5 \mathrm{~d}$ of abomasal EAA infusion, indicating suppression of the first arm of the UPR in favor of a greater secretory cell number. In the present experiment, the increase in expression of PPP1R15A in response to PT (on the HF diet only), independent of DDIT3, does not support an adaptive UPR, but the protein product 
of PPP1R15A translation is activatory toward protein synthesis. This outcome is partially consistent with the greater milk protein yield observed in response to PT, regardless of dietary fat level. The proportion of XBP1s to $X B P 1 \mathrm{u}$ represents the proportion of active $X B P 1$ available for translation relative to inactive $X B P 1$. The increase in this proportion in response to $\mathrm{PT}$ suggests induction of the IRE1-mediated arm of the UPR to enhance protein secretory capacity, although the tendency for a PT $\times$ FT interaction indicates this may occur on LF diets only. Similarly, Nichols et al. (2017) observed an increase in $X B P 1 \mathrm{~s} / X B P 1 \mathrm{u}$ in response to abomasal EAA infusion. Spliced $X B P 1$ is required for ER biogenesis and expansion in murine cells with a high secretory load, such as gastric, pancreatic, and mammary cells (Lee et al., 2005; Huh et al., 2010; Davis et al., 2016), and its expression is increased at the onset of lactation in bovine mammary glands (Yonekura et al., 2018). In summary, PT increased PPP1R15A expression at the HF level independent of an adaptive UPR response, but in line with increased protein synthesis stimulated by PT. Splicing of $X B P 1$, in line with ER biogenesis, was induced by PT more strongly at the LF level, potentially in support of greater cellular secretory capacity and increased milk protein, fat, and lactose yield in response to PT.

To our knowledge, the UPR in mammary cells has not been previously investigated in response to dietary fat supplementation. The XBP1 signaling cascade is activated in response to high fat conditions in murine liver and skeletal muscle during ER stress (Wang et al., 2006; Deldicque et al., 2010) and in adipose during lactation (Gregor et al., 2013). Independent from canonical UPR and ER-stress signaling, hepatic XBP1 splicing was upregulated to promote downstream activation of de novo lipogenic genes (Lee et al., 2008). In response to $\mathrm{FT}$ in the current study, the proportion of $X B P 1$ s to $X B P 1 \mathrm{u}$ tended to increase, but only at the HP level. Expression of XBP1 in mammary glands might differ compared with liver or adipose due to differences in tissue function, where FA are stored by liver and adipose but secreted by mammary glands.

Overall, although PT increased milk protein, fat (tendency only), and lactose yield independent of FT, we found that the cellular response to PT depended on FT. At the LF level, PT stimulated splicing of XBP1, suggesting ER biogenesis in support of milk component secretory capacity. In response to PT at the HF level, stimulation of milk protein synthesis may have been supported through PPP1R15A expression, which increased in response to PT specifically at the HF level. In summary, when energy is supplemented from protein, mammary secretory capacity may be increased through ER biogenesis stimulated by activated XBP1. When extra energy is supplemented from protein and fat together, expression of PPP1R15A encoding GADD34 may promote increased protein secretory activity. Moreover, the changes we observed in expression of spliced XBP1 suggest upregulation of the IRE1-mediated UPR arm, but with no change in expression of HSPA5. A separate control mechanism for the XBP1 cascade has become apparent in hepatic lipogenesis (Lee et al., 2008), in adipocytes during lactation (Gregor et al., 2013), and in innate immune cells (Martinon et al., 2010). Our findings in lactating bovine mammary glands agree with those of Nichols et al. (2017) and show that separate components of the UPR may be affected by mammary-sequestered nutrients, but the role this plays in secretory cell differentiation, ER functionality, and milk component synthesis in mammary epithelial cells remains to be definitively established.

\section{CONCLUSIONS}

Energy from protein increased mammary catabolism of BCAA, which was associated with higher expression of $B C A T 1$ but only at the LF level. Energy from protein tended to decrease $B C K D H A$ expression, suggesting that transamination of BCAA was occurring faster than their catabolism to CoA derivatives. Energy from protein decreased ME2 expression, which also only occurred at the LF level. Taken together, these results may suggest a link between regulation of AA catabolism, specifically the BCAA, and anaplerotic flux through the TCA cycle. We detected no effects of energy from protein or fat on $P C K 2$ expression. Increased yield of de novo FA stimulated by energy from protein was not associated with increased $I D H 1$ or $A C C 1$ expression. mRNA expression of these enzymes was also not affected by energy from fat, which agrees with increased preformed FA yield and no change in de novo FA yield during fat supplementation. mRNA expression of genes related to the UPR and ER biogenesis were affected by energy from protein that depended on dietary fat level. At the LF level, energy from protein activated $X B P 1$, possibly in support of secretory cell adaptation to secretory load. In response to protein at the HF level, stimulation of milk protein synthesis may have been supported through PPP1R15A expression, encoding the GADD34 protein. Overall, our findings show that mammary cells use aminogenic and lipogenic precursors differently in support of milk component production when AA and FA supply at the gland level is altered by dietary intervention. They also suggest that mammary cells respond to increased AA supply through mechanisms of ER homeostasis dependent on the presence of energy from fat. 


\section{ACKNOWLEDGMENTS}

The authors acknowledge the technical assistance of Mieke Langen and Jos Versteegen (Trouw Nutrition Ruminant Research Centre), Jasper te Winkel (student of Wageningen University, Wageningen, the Netherlands), Marthe Hendriks Franssen and Ralph Litjens (MasterLab, Boxmeer, the Netherlands), and Jurgen van Baal (Animal Nutrition Group, Wageningen University and Research, the Netherlands). This research was conducted by Wageningen University and Research (Wageningen Livestock Research, Wageningen, the Netherlands), commissioned and funded by the Ministry of Agriculture, Nature and Food Quality (The Hague, the Netherlands) within the framework of Policy Support Research theme "Feed4Foodure" (BO-31.03005-001; TKI-AF12039), and by the Vereniging Diervoederonderzoek Nederland (Rijswijk, the Netherlands).

\section{REFERENCES}

Abdelatty, A. M., M. E. Iwaniuk, M. Garcia, K. M. Moyes, B. B. Teter, P. Delmonte, A. K. G. Kadegowda, M. A. Tony, F. F. Mohamad, and R. A. Erdman. 2017. Effect of short-term feed restriction on temporal changes in milk components and mammary lipogenic gene expression in mid-lactation Holstein dairy cows. J. Dairy Sci. 100:4000-4013.

Agca, C., R. B. Greenfield, J. R. Hartwell, and S. S. Donkin. 2002. Cloning and characterization of bovine cytosolic and mitochondrial PEPCK during transition to lactation. Physiol. Genomics 11:53-63.

Ahnadi, C. E., N. Beswick, L. Delbecchi, J. J. Kennelly, and P. Lacasse. 2002. Addition of fish oil to diets for dairy cows. II. Effects on milk fat and gene expression of mammary lipogenic enzymes. J. Dairy Res. 69:521-531.

Andersen, C. L., J. L. Jensen, and T. F. Ørntoft. 2004. Normalization of real-time quantitative reverse transcription-PCR data: A model-based variance estimation approach to identify genes suited for normalization, applied to bladder and colon cancer data sets. Cancer Res. 64:5245-5250.

Appuhamy, J. A. D. R. N., A. L. Bell, W. A. D. Nayananjalie, J. Escobar, and M. D. Hanigan. 2011. Essential amino acids regulate both initiation and elongation of mRNA translation independent of insulin in MAC-T cells and bovine mammary tissue slices. J. Nutr. 141:1209-1215.

Bauman, D. E., R. E. Brown, and C. L. Davis. 1970. Pathways of fatty acid synthesis and reducing equivalent generation in mammary gland of rat, sow, and cow. Arch. Biochem. Biophys. 140:237-244.

Baumgard, L. H., E. Matitashvili, B. A. Corl, D. A. Dwyer, and D. E. Bauman. 2002. Trans-10, cis-12 conjugated linoleic acid decreases lipogenic rates and expression of genes involved in milk lipid synthesis in dairy cows. J. Dairy Sci. 85:2155-2163.

Bequette, B. J., F. R. C. Backwell, J. C. MacRae, G. E. Lobley, L. A. Crompton, J. A. Metcalf, and J. D. Sutton. 1996a. Effect of intravenous amino acid infusion on leucine oxidation across the mammary gland of the lactating goat. J. Dairy Sci. 79:2217-2224.

Bequette, B. J., C. E. Kyle, L. A. Crompton, S. E. Anderson, and M. D. Hanigan. 2002. Protein metabolism in lactating goats subjected to the insulin clamp. J. Dairy Sci. 85:1546-1555.

Bequette, B. J., J. A. Metcalf, D. Wray-Cahen, F. R. C. Backwell, J. D. Sutton, M. A. Lomax, L. C. MacRae, and G. E. Lobley. 1996b. Leucine and protein metabolism in the lactating dairy cow mammary gland: Responses to supplemental dietary crude protein intake. J. Dairy Res. 63:209-222.

Bernard, L., P. G. Toral, and Y. Chilliard. 2017. Comparison of mammary lipid metabolism in dairy cows and goats fed diets supple- mented with starch, plant oil, or fish oil. J. Dairy Sci. 100:93389351.

Boutinaud, M., M. H. Ben Chedly, E. Delamaire, and J. GuinardFlament. 2008. Milking and feed restriction regulate transcripts for mammary epithelial cells purified from milk. J. Dairy Sci. 91:988-998.

Brenaut, P., R. Bangera, C. Bevilacqua, E. Rebours, C. Cebo, and P. Martin. 2012. Validation of RNA isolated from milk fat globules to profile mammary epithelial cell expression during lactation and transcriptional response to bacterial infection. J. Dairy Sci. 95:6130-6144.

Brosnan, J. T., and M. E. Brosnan. 2006. Branched-chain amino acids: Enzyme and substrate regulation. J. Nutr. 136:207S-211S.

Burgos, S. A., M. Dai, and J. P. Cant. 2010. Nutrient availability and lactogenic hormones regulate mammary protein synthesis through the mammalian target of rapamycin signaling pathway. J. Dairy Sci. 93:153-161.

Burgos, S. A., J. J. M. Kim, M. Dai, and J. P. Cant. 2013. Energy depletion of bovine mammary epithelial cells activates AMPK and suppresses protein synthesis through inhibition of mTORC1 signaling. Horm. Metab. Res. 45:183-189.

Cánovas, A., G. Rincón, C. Bevilacqua, A. Islas-Trejo, P. Brenaut, R. C. Hovey, M. Boutinaud, C. Morgenthaler, M. K. VanKlompenberg, P. Martin, and J. F. Medrano. 2014. Comparison of five different RNA sources to examine the lactating bovine mammary gland transcriptome using RNA-sequencing. Sci. Rep. 4:5297.

Cant, J. P., J. J. M. Kim, S. R. L. Cieslar, and J. Doelman. 2018 Symposium review: Amino acid uptake by the mammary glands: Where does the control lie? J. Dairy Sci. 101:5655-5666.

Chang, G. G., and L. Tong. 2003. Structure and function of malic enzymes, a new class of oxidative decarboxylases. Biochemistry 42:12721-12733.

Curtis, R. V., J. J. M. Kim, D. L. Bajramaj, J. Doelman, V. R. Osborne, and J. P. Cant. 2014. Decline in mammary translational capacity during intravenous glucose infusion into lactating dairy cows. J. Dairy Sci. 97:430-438.

Davis, K. R., S. L. Giesy, Q. Long, C. S. Krumm, K. J. Harvatine, and Y. R. Boisclair. 2016. XBP1 regulates the biosynthetic capacity of the mammary gland during lactation by controlling epithelial expansion and endoplasmic reticulum formation. Endocrinology 157:417-428.

Davis, S. R., and T. B. Mepham. 1976. Metabolism of L- $\left[\mathrm{U}_{-}{ }^{14} \mathrm{C}\right]$ valine, L- $\left[\mathrm{U}_{-}{ }^{14} \mathrm{C}\right]$ leucine, L- $\left[\mathrm{U}_{-}{ }^{14} \mathrm{C}\right]$ histidine and $\mathrm{L}-\left[\mathrm{U}_{-}-{ }^{14} \mathrm{C}\right]$ phenylalanine by the isolated guinea-pig mammary gland. Biochem. J. 156:553-560.

Deldicque, L., P. D. Cani, A. Philp, J. Raymackers, P. J. Meakin, M. L. J. Ashford, N. M. Delzenne, M. Francaux, and K. Baar. 2010 The unfolded protein response is activated in skeletal muscle by high-fat feeding: Role in the downregulation of protein synthesis. Am. J. Physiol. Endocrinol. Metab. 299:E695-E705.

DeSantiago, S., N. Torres, A. Suryawan, A. R. Tovar, and S. M. Hutson. 1998. Regulation of branched-chain amino acid metabolism in the lactating rat. J. Nutr. 128:1165-1171.

Doelman, J., R. V. Curtis, M. Carson, J. J. M. Kim, J. A. Metcalf, and J. P. Cant. 2015. Essential amino acid infusions stimulate mammary expression of eukaryotic initiation factor $2 \mathrm{~B} \varepsilon$ but milk protein yield is not increased during an imbalance. J. Dairy Sci. 98:4499-4508.

Farrell, H. M. Jr., J. T. Deeney, K. Tubbs, and R. A. Walsh. 1987. Role of the isocitrate dehydrogenases and other Krebs cycle enzymes in lactating bovine mammary gland. J. Dairy Sci. 70:781-788.

Gregor, M. F., E. S. Misch, L. Yang, S. Hummasti, K. E. Inouye, A. Lee, B. Bierie, and G. S. Hotamisligil. 2013. The role of adipocyte XBP1 in metabolic regulation during lactation. Cell Rep. 3:1430-1439.

Harding, H. P., H. Zeng, Y. Zhang, R. Jungries, P. Chung, H. Plesken, D. D. Sabatini, and D. Ron. 2001. Diabetes mellitus and exocrine pancreatic dysfunction in Perk - / - mice reveals a role for translational control in secretory cell survival. Mol. Cell 7:1153-1163.

Heid, H. W., and T. W. Keenan. 2005. Intracellular origin and secretion of milk fat globules. Eur. J. Cell Biol. 84:245-258. 
Hetz, C., E. Chevet, and S. A. Oakes. 2015. Proteostasis control by the unfolded protein response. Nat. Cell Biol. 17:829-838.

Huston, G. E., and S. Patton. 1990. Factors related to the formation of cytoplasmic crescents on milk fat globules. J. Dairy Sci. 73:2061-2066.

Huh, W. J., E. Esen, J. H. Geahlen, A. J. Bredemeyer, A.-H. Lee, G. Shi, S. F. Konieczny, L. H. Glimcher, and J. C. Mills. 2010. XBP1 controls maturation of gastric zymogenic cells by induction of MIST1 and expansion of the rough endoplasmic reticulum. Gastroenterology 139:2038-2049.

Koh, H. J., S. M. Lee, B. G. Son, S. H. Lee, Z. Y. Ryoo, K. T. Chang, J. W. Park, D. C. Park, B. J. Song, R. L. Veech, H. Song, and T. L. Huh. 2004. Cytosolic NADP ${ }^{+}$-dependent isocitrate dehydrogenase plays a key role in lipid metabolism. J. Biol. Chem. 279:39968-39974.

Lee, A. H., G. C. Chu, N. N. Iwakoshi, and L. H. Glimcher. 2005. XBP-1 is required for biogenesis of cellular secretory machinery of exocrine glands. EMBO J. 24:4368-4380.

Lee, A. H., E. F. Scapa, D. E. Cohen, and L. H. Glimcher. 2008. Regulation of hepatic lipogenesis by the translation factor XBP1. Science 320:1492-1496.

Lemay, D. G., R. C. Hovey, S. R. Hartono, K. Hinde, J. T. Smilowitz, F. Ventimiglia, K. A. Schmidt, J. W. S. Lee, A. Islas-Trejo, P. Ivo Silva, I. Korf, J. F. Medrano, P. A. Barry, and J. German. 2013. Sequencing the transcriptome of milk production: Milk trumps mammary tissue. BMC Genomics 14:872.

Liu, W., A. V. Capuco, and D. F. Romagnolo. 2006. Expression of cytosolic $\mathrm{NADP}^{+}$-dependent isocitrate dehydrogenase in bovine mammary epithelium: Modulation by regulators of differentiation and metabolic effectors. Exp. Biol. Med. (Maywood) 231:599-610.

Livak, K. J., and T. D. Schmittgen. 2001. Analysis of relative gene expression data using real-time quantitative PCR and the $2^{-\Delta \Delta \mathrm{CT}}$ method. Methods 25:402-408.

Ma, Y., and L. M. Hendershot. 2003. Delineation of a negative feedback regulatory loop that controls protein translation during endoplasmic reticulum stress. J. Biol. Chem. 278:34864-34873.

Mandella, R. D., and L. A. Sauer. 1975. The mitochondrial malic enzymes. I. Submitochondrial localization and purification and properties of the NAD (P)+-dependent enzyme from adrenal cortex. J. Biol. Chem. 250:5877-5884.

Maningat, P. D., P. Sen, A. L. Sunehag, D. L. Hadsell, and M. W. Haymond. 2007. Regulation of gene expression in human mammary epithelium: Effect of breast pumping. J. Endocrinol. 195:503-511.

Martinon, F., X. Chen, A.-H. Lee, and L. H. Glimcher. 2010. TLR activation of the transcription factor XBP1 regulates innate immune responses in macrophages. Nat. Immunol. 11:411-418.

Méndez-Lucas, A., P. Hyroššová, L. Novellasdemunt, F. Viñals, and J. C. Perales. 2014. Mitochondrial phosphoenolpyruvate carboxykinase (PEPCK-M) is a pro-survival, endoplasmic reticulum (ER) stress response gene involved in tumor cell adaptation to nutrient availability. J. Biol. Chem. 289:22090-22102.

Nichols, K., A. Bannink, S. Pacheco, H. J. van Valenberg, J. Dijkstra, and H. van Laar. 2018. Feed and nitrogen efficiency are affected differently but milk lactose production is stimulated equally when isoenergetic protein and fat is supplemented in lactating dairy cow diets. J. Dairy Sci. 101:7857-7870.

Nichols, K., J. Doelman, J. J. M. Kim, M. Carson, J. A. Metcalf, and J. P. Cant. 2017. Exogenous essential amino acids stimulate an adaptive unfolded protein response in the mammary glands of lactating cows. J. Dairy Sci. 100:5909-5921.

Nichols, K., H. van Laar, A. Bannink, and J. Dijkstra. 2019. Mammary gland utilization of amino acids and energy metabolites differs when dairy cow rations are isoenergetically supplemented with protein and fat. J. Dairy Sci. 102:1160-1175.

Ollier, S., C. Leroux, A. de la Foye, L. Bernard, and Y. Chilliard. 2009. Whole intact rapeseeds or sunflower oil in high-forage or highconcentrate diets affects milk yield, milk composition, and mammary gene expression profile in goats. J. Dairy Sci. 92:5544-5560.

Owen, O. E., S. C. Kalhan, and R. W. Hanson. 2002. The key role of anaplerosis and cataplerosis for citric acid cycle function. J. Biol. Chem. 277:30409-30412.
Peterson, D. G., E. A. Matitashvili, and D. E. Bauman. 2003. Diet-induced milk fat depression in dairy cows results in increased trans-10, cis-12 CLA in milk fat and coordinate suppression of mRNA abundance for mammary enzymes involved in milk fat synthesis. J. Nutr. 133:3098-3102.

Piperova, L. S., B. B. Teter, I. Bruckental, J. Sampugna, S. E. Mills, M. P. Yurawecz, J. Fritsche, K. Ku, and R. A. Erdman. 2000. Mammary lipogenic enzyme activity, trans fatty acids and conjugated linoleic acids are altered in lactating dairy cows fed a milk fat-depressing diet. J. Nutr. 130:2568-2574.

Pongratz, R. L., R. G. Kibbey, G. I. Shulman, and G. W. Cline. 2007. Cytosolic and mitochondrial malic enzyme isoforms differentially control insulin secretion. J. Biol. Chem. 282:200-207.

Proud, C. G. 2005. eIF2 and the control of cell physiology. Semin. Cell Dev. Biol. 16:3-12.

Raggio, G., S. Lemosquet, G. E. Lobley, H. Rulquin, and H. Lapierre. 2006. Effect of casein and propionate supply on mammary protein metabolism in lactating dairy cows. J. Dairy Sci. 89:4340-4351.

Reimold, A. M., N. N. Iwakoshi, J. Manis, P. Vallabhajosyula, E. Szomolanyi-Tsuda, E. M. Gravellese, D. Friend, M. J. Grusby, F. Alt, and L. H. Glimcher. 2001. Plasma cell differentiation requires the transcription factor XBP-1. Nature 412:300-307.

Rius, A. G., J. A. D. R. N. Appuhamy, J. Cyriac, D. Kirovski, O. Becvar, J. Escobar, M. L. McGilliard, B. J. Bequette, R. M. Akers, and M. D. Hanigan. 2010. Regulation of protein synthesis in mammary glands of lactating dairy cows by starch and amino acids. J. Dairy Sci. 93:3114-3127.

Roets, E., A. Massart-Leën, G. Peeters, and R. Verbeke. 1983. Metabolism of leucine by the isolated perfused goat udder. J. Dairy Res. 50:413-424.

Roets, E., A. Massart-Leën, R. Verbeke, and G. Peeters. 1979. Metabolism of $\left[\mathrm{U}^{14}{ }^{14} \mathrm{C} ; 2,3-{ }^{3} \mathrm{H}\right]$-L-valine by the isolated perfused goat udder. J. Dairy Res. 46:47-57.

Scott, R. A., D. E. Bauman, and J. H. Clark. 1976. Cellular gluconeogenesis by lactating bovine mammary tissue. J. Dairy Sci. 59:50-56.

Sriburi, R., S. Jackowski, K. Mori, and J. W. Brewer. 2004. XBP1: A link between the unfolded protein response, lipid biosynthesis, and biogenesis of the endoplasmic reticulum. J. Cell Biol. 167:35-41.

Toerien, C. A., D. R. Trout, and J. P. Cant. 2010. Nutritional stimulation of milk protein yield of cows is associated with changes in phosphorylation of mammary eukaryotic initiation factor 2 and ribosomal S6 kinase 1. J. Nutr. 140:285-292.

Tsuchiya, M., Y. Koizumi, S. Hayashi, M. Hanaoka, Y. Tokutake, and S. Yonekura. 2017. The role of unfolded protein response in differentiation of mammary epithelial cells. Biochem. Biophys. Res. Commun. 484:903-908.

Walter, P., and D. Ron. 2011. The unfolded protein response: From stress pathway to homeostatic regulation. Science 334:1081-1086.

Wang, D., Y. Wei, and M. J. Pagliassotti. 2006. Saturated fatty acids promote endoplasmic reticulum stress and liver injury in rats with hepatic steatosis. Endocrinology 147:943-951.

Wohlt, J. E., J. H. Clark, R. G. Derrig, and C. L. Davis. 1977. Valine, leucine, and isoleucine metabolism by lactating bovine mammary tissue. J. Dairy Sci. 60:1875-1882.

Wood, H. G., S. Joffe, R. Gillespie, R. G. Hansen, and H. Hardenbrook. 1958. Lactose synthesis. IV. The synthesis of milk constituents after unilateral injection of glycerol-1,3- $\mathrm{C}^{14}$ into the pudic artery. J. Biol. Chem. 233:1264-1270.

Wood, H. G., G. J. Peeters, R. Verbeke, M. Lauryssens, and B. Jacobson. 1965. Estimation of the pentose cycle in the perfused cow's udder. Biochem. J. 96:607-615.

Wright, T. C., J. P. Cant, J. T. Brenna, and B. W. McBride. 2006. Acetyl CoA carboxylase shares control of fatty acid synthesis with fatty acid synthase in bovine mammary homogenate. J. Dairy Sci. $89: 2552-2558$.

Yonekura, S., M. Tsuchiya, Y. Tokutake, M. Mizusawa, M. Nakano, M. Miyaji, H. Ishizaki, and S. Haga. 2018. The unfolded protein response is involved in both differentiation and apoptosis of bovine mammary epithelial cells. J. Dairy Sci. 101:3568-3578. 